\title{
Film Literacy Culture and Identity Expression of Madurese Women in Pesantren (Santriwati) in Madura
}

\author{
Zakiyatul Mufidah \\ English Literature \\ University of Trunojoyo Madura \\ Bangkalan, Indonesia \\ zakiyatul.mufidah@trunojoyo.ac.id
}

\author{
Afiifah Al Rosyiidah \\ English Literature \\ University of Trunojoyo Madura \\ Bangkalan, Indonesia \\ afifah.rosyidah@gmail.com
}

\begin{abstract}
Literacy culture of film and other literary works such as novel or drama among santriwati (muslim women living and studying in pesantren) is interesting to discuss since they have unique characteristics. They are living and learning religiosity in pesantren and at the same time they are studying sciences in college or university. Normally, living in pesantren is tied by a strict religious norms and traditions. There are certain rules as santri that they oblige to obey. On the other hand, as university students, dealing with more flexible and open culture is unavoidable. They need reading references, watching films and enjoying novels or other literary works as part of campus life.

This paper tries to examine how literacy culture among santriwati relates to their identity expression. It also aims at identifying the form of identity expression expressed by santriwati in Madura. There are 15 santriwati from different pesantren in Madura to be observed and asked as the respondents. Qualitative research is applied in this study as it explains particular cases and phenomena in certain area by using words and sentences. The results of this study indicate that the literacy culture of film among santriwati to some extent relate to their identity expression although they could hardly express it through their behavior as common people. This slight relation is because of their strong commitment to the religious norms and values that strongly encourage them to express their identity expression as a good santri.
\end{abstract}

Keywords-literacy culture; film; identity expression; santriwati; pesantren

\section{INTRODUCTION}

Literacy culture among students living in pesantren (santri) is one of the main characteristics possessed by university students in Madura. They are studying in Islamic boarding schools and at the same time are studying in college or university. As students and santri, literacy culture of film cannot be denied because they need reading references as well as entertainment in their lecture process. Thus, the literacy culture among santri is increasing in the current digital era, even more so with increasingly easy internet access using free Wi-Fi provided in almost all public spaces.

The choice of literature sources in the form of watching movies or novels among santriwati certainly becomes an interesting discussion because literary choices will indirectly internalize into the mindset, ideas, behavior of the reader or audience. Some of the forms of behavior and cultural adoption through the characters displayed in literary sources from both films and novels can be seen through trending topics on social media. For example, during the Dillan teen romance movie booming, almost the entire millennial generations were able to recognize and mention the characters in it. In addition, when the booming novels such as Negeri 5 Menara, Laskar Pelangi, I Love Kyaiku, Ayat Ayat Cinta, they glorified the sense of love and suddenly became a compulsory consumption for millennial generation including santriwati.

The themes raised by the majority of popular literature contain stories of romance, love, and the dynamics of the lives of young people in school or on campus. These themes are indeed appealing and interesting because they are very close to the lives of young people who generally have a passionate desire for love and passion for the opposite sex, as well as the amount of desire to be known, recognized and accepted by the surrounding environment. The desire to be recognized as particular identity is naturally felt by all individuals, including santriwati. In this phase, they have begun to have an interest in the opposite sex, desires that are affective (accept and give love), and awareness to show their personal identity (selfidentity). In addition, at the same time, they are also experiencing a process of searching for identity, so the issue of awareness of personal identity and group identity is also very instrumental in the process of forming their self-identity.

Santriwati women are a very unique group, they are a group that is both potential and vulnerable. This group of young women lives and processes in two places simultaneously, namely in a boarding school environment with a variety of strong rules, traditions and religious norms. At the same time, they are also in the midst of campus life which tends to be more fluid, flexible and dynamic. As female students, they have great potential to hold fast to maintaining a strong religious tradition, but they are also vulnerable to issues of sexual behavior and expression of identity which are important issues in their life phases. Behavior of sexuality and expression of identity is not something that can be underestimated, because these two things are the basic needs of individuals that 
must be met or channeled. Therefore, they also become a group that is vulnerable to identity expression patterns that they experience in their daily lives.

This study aims to explain how literacy culture among Madurese female students is related to their identity expression. In addition, this research is also intended to identify forms of the identity expression of Madurese female student identity. By knowing the forms, patterns, and images of literary culture among female students, it is hoped that they can draw a red thread of connection with their expression of identity.

Among all of the other theorists that propose the concept of identity, which is one of the issues in Cultural Studies, Stuart Hall is the most well-known scholar. Hall argued that identity was not merely a theory of the knowing subject, but rather a theory of discursive practice. Identification is constructed on the back of recognition of some common or shared characteristics with another person or group, and with the natural closure of solidarity established on this foundation [6].

Identity, therefore, deals with not only the 'self', it rather engages with the question of how ' $\mathrm{I}$ ' is categorized in a particular social group, which then leads to social identity. Hogg and Abrams in Stets and Burke [4] defines social identity as a person's knowledge that he/she belongs to a social category or group. In the theory of social identity, Tajfel and Turner [3] agree and explain that part of a person's concept of self comes from the groups to which that person belongs. An individual does not just have a personal selfhood, but multiple selves and identities associated with their affiliated groups [5]. Linking back to Hall's theory, this idea is in line with the second concept of identity that he proposed in his book which is called the sociological subject. The sociological subject refers to humans as social beings who need to interact with each other. Interaction is part of humans' life, and for that reason, the 'self' and 'surroundings' can form identity. One's actions will inevitably be influenced by those who surround him/her. Therefore, identity expression is embodied through one's social interaction with their surroundings. It is essential since people tend to easily judge individuals based on their appearance. How they dress and how they interact with others. Identity is afterwards become the prominent issue which leads to how individuals want to bear themselves and how they want to be addressed in society.

\section{METHODS}

This study is a descriptive qualitative study as it deals with words, interpretation, and phenomena explanation. As many as 15 respondents are involved from 3 regencies across Madura; Bangkalan, Pamekasan and Sumenep. The respondents were chosen deliberately to meet the research focus. They are female university students who at the same time living in Pesantren as Santriwati. All the respondents answered the prepared structured question from the questionnaire that related to the issue of film literacy and its relation with their identity expression. The data from the respondents are then being interpreted and analyzed by using the theory of gender and identity expression.

\section{RESULTS AND DISCUSSION}

\section{A. Film Literacy Culture}

Being Female Santri (santriwati) is special due to some particular reasons. First of all, they are female university students who are likely having the same passion and desire as the common peer group. However, the values and religious norms might restrain them from any common behavior and attitude. For example, they probably want to express their identity and existence by showing who they are from the way they dress, the way they speak and act. Through their daily appearance they can easily be identified as particular person. Second of all, having interacted with public widely in campus life will certainly enable them to access any references and entertainment from both off line and online media. The saturating media especially film cannot be avoided. Santriwati as one of potential groups who enjoy this media might get the impact or influence upon the watching film. This study tries to examine how the culture of film literacy relates to how Santriwati express their identity as female santri.

Based on the data taken from the respondents' answer, it can clearly be seen that almost all female santri enjoy particular genre of film. Most of film genre female santri watched and enjoyed is drama and romantic film either coming from Indonesia or western or USA. This sort of genre might interest them since it is considerably close with their real life. They are university students aged between 19-23 who are supposed to concern with the issue of romantic love, friendship, and school or campus life. The genre of romance, drama and comedy are among the favorites they pretty much often to watch. Friendship is another theme of film they usually like to watch. The biggest reason according to most respondents is that they think that kind of film genre can become an inspiration to their life. That film can also be their motivation according to some of the respondents. Obviously, the theme of the romantic film can teach them how to be a strong hearted character, how to win their lover's heart and how to struggle their love when it comes to a pressing situation. The characters' characterization through the film has highly been one of the repercussions on how they reflect to their real life. Therefore, most of respondents agree that they are often amazed and adored particular characters in the film. When answering the question of what sort of characters they really like, all of the respondents agreed to like handsome or beautiful characters in the film. In addition, a special character who is kind hearted, good characterization and has positive characteristics is the most chosen by the respondents as the protagonists should be. They are compelled by how the main characters (good and usually handsome or beautiful) live their life in whatsoever condition. It is always reflected to real life the common people face in their daily live.

Henceforth, santriwati in Madura who are also university students are already familiar with film culture. None of the respondents have never watched film. They can even mention 
popular films and famous characters being heralded by media and television. It means that watching film is already one of their preferences in their spare time. It is film literacy culture which they have already practiced even they are living in pesantren in which the rules and the regulations are usually tighter and more strict to the students.

\section{B. Identity Expression Through Fashion, Behaviour and Make Up}

Identity, to begin with, is a somehow tricky concept and cannot actually be clearly defined. The definition of identity might refer to the answer of the question "what is one's identity?" Identity might be fluid and changing over the time in line with one's self development and environment. It is a crucial issue since identity is most likely dealing with selfreflection and description. Barker [1] stated to explore identity is to enquire: how do we see ourselves and how others see us. So, it is appearance including the way of dressing that will determine who and how we actually are. Davis [2] stated that "you are what you wear". The term fashion itself according to Davis [2] differs from its other neighbor terms in a way we relate the kind of clothes with the meaning it conveys. It includes brands, fashion items, clothing styles and hijab styles.

According to data taken form the respondents, female santri prefer to watch film with beautiful main characters wearing hijab. They claim that beautiful women wearing hijab is one of their role model. They adore the way muslimah are being portrayed through particular films. To be more precise, they like female characters who wear fashionable hijab and it relates to their desire to wear fashionable hijab instead of syar'i hijab. Fashionable hijab is hijab which its cut and model suits the recent style although it does not always fulfill the good criteria of hijab which should cover the breast area. Conversely, syar'i hijab is usually referred to a long, wide and opaque hijab that cover the breast area. However, it seems contradict with some other respondents answer when being asked which one they prefer to wear, either syar'i or fashionable hijab. Most of them answered syar'i hijab. They like fashionable hijab yet the tradition in pesantren disables them to do so. According to the researcher one of the biggest factors that influence their dress or appearance is from the film they watch or any other media such as magazines and visual advertisements. Yet, they tend to strictly hold the religious rules and norms to keep wearing syar'i hijab when they go outside to demonstrate that they are santri.

Another fashion item which santriwati used to wear is long skirt. Although for some people wearing long skirt is not dynamic and outdated, they keep wearing it to show that they are santri. None of santri living in pesantren is wearing trousers. Long skirt symbolizes politeness and gracefulness according to most of them. Even so, when being asked which one they prefer long skirt or trousers, still some of them like and want to wear trousers. However, in the real situation they must wear long skirt as one of pesantren rules for santriwati.
Long skirt is overall become the identity of santriwati living in pesantren.

Tajfel \& Turner [3] mentioned that individuals will not interact as individuals, on the basis of their individual characteristics, but as members of their groups standing in certain defined relationship. This statement is in line with result of the study taken from the answers of the respondents. All respondents seem agree to answer that they are confident to be identified as santri. In other occasion, the question asking whether they are ever having problem with low selfesteem because of their status as santriwati, all the respondents answer "NO". They just feel confident when their friends and communities recognize them as santri. Being santri is an identity which makes them more confident when they get along with society instead. Being asked deeper about their identity as santri, all the respondents seem agree that factors such as attitude and clothing style are the two prominent things that signify them as santri. They feel very confident of being santri because they think they can uphold the good behavior and maintain the religious norms and values. One of the attitudes the researcher observed is how they get along with the older ones especially their teachers and parents. When shaking hands with older ones, they will not only shake the hands but they also bent their body a little bit while kissing the back of the hands. It clearly signifies that they give a big salutation and respect to the older ones especially their teachers. This sort of behavior might not be found in the culture of ordinary students, yet it is pesantren culture which teaches them on how to give honor to their teachers and older ones.

In regards with the use of makeup, it is hard to find any santri apply excessive makeup on their faces in daily activity. According to the researcher observation they only apply a simple makeup such as powder and a sheer lipstick or lipgloss if necessary. It is in line with their answer when being asked whether they wear makeup or not. Almost all the respondents said they just apply the simple one on their faces such as powder. They do not like any makeup which might invite male's attention. They prefer to appear as what they are without covering with too much makeup.

The identity expression of Madurese santriwati based on the result above indicates that they actually have desire to express their identity as female santri through common fashion and hijab as they often watch in films. Film literacy culture has highly influence on their perception about appearance and identity expression. However, it is religious norms and pesantren cultures that alleviate their desire in expressig their self-identity as ordinary women. In fact, they prefer to keep maintaining what they have learned from pesantren tradition and culture. They are proud and confident to be identified as santri as they behave and express it through the way they dress, the way they behave and the way they think about physical beauty and appearance. Therefore, even film literacy culture has become the repercussion for 
santriwati to their notion, desire and perspective, yet their identity expression does not change.

\section{Values of Santriwati in Madura}

The values of santriwati in this study refer to the things santriwati see as important and attached to them as part of their identity. Some of the values are certainly interwoven with religious norms as Moslem. According to the data taken from the respondents' answer, there are three values they believe to be their identity which distinguish them from others (non-santri). Firstly, they confidently answer that as santriwati, they feel proud since they learn more religious rules and knowledge. They get sizeable lessons from pesantren that can equip them to face the life and hereafter. Their life orientation does not only lie on the today's life but they also seriously prepare the life hereafter. Some of the respondents even claimed that as santri, they are most likely conditioned to be more obedient in doing religious obligation. Secondly, their answers mostly claim about being polite in behavior. They learn how to behave in a good manner and how to honor someone else. Politeness is an important value that more likely to differentiate them from others. Thirdly, it is the status of santri itself that makes them proud. They just think that santri is different and it is their pride to be different from common (ordinary) ones. Henceforth, identity expression of santriwati in Madura can be categorized as one of essential issues that can reveal how santriwati in Madura actually define and identify themselves. Santriwati in Madura already have a huge awareness on their own identity as Santri.

\section{CONCLUSION}

Film literacy culture among santriwati in Madura has highly influenced the life of santri living in pesantren and studying at university at the same time. The influential factors such as identity expression through their fashion preferences, behavior and makeup application for their daily life have made them proud to be identified as Santriwati. However, the religious values and pesantren cultures have somehow controlled them to express their desire and willingness. They tend to strongly uphold the norms and cultures they learn from pesantren.

\section{REFERENCES}

[1] C. Barker, Cultural Studies: Theory and Practice. UK: The Alden Press, 2000.

[2] F. Davis, Fashion, Culture, and Identity. USA: The University of Chicago Press, 1994.

[3] H. Tajfel, \& J. C. Turner, "The Social Identity Theory of Intergroup Behavior," Psychology of Intergroup Relations, pp. 7-24, 1986.

[4] J. E. Stets, \& P. J. Burke, "Identity Theory and Social Identity Theory," Social Psychology Quarterly, pp. 224-237, 2000.

[5] L. David, "Social Identity Theory (Tajfel, Turner)," Learning Theories, [Online]. Available: https://www.learningtheories.com/social-identity-theory-tajfel-turner.html. [Accessed: 02Nov-2018], 2015.

[6] S. Hall, \& P. D. Gay, "Who Needs Identity?," in Questions of Cultural Identity, pp. 1-16. London: SAGE Publications, 1996. 